\title{
KETERAMPILAN MANAJERIAL KEPALA MADRASAH DALAM MENINGKATKAN KINERJA GURU DI MADRASAH ALIYAHAL-FALAH ARUNGKEKE KABUPATENJENEPONTO
}

\begin{abstract}
Sulaeman $^{1}$
Abstract. This study was designed using a qualitative descriptive approach correlational manifold. Collecting data using three types of questionnaires about managerial skills, leadership models, and teacher performance. Data were analyzed using descriptive statistics. The results showed that (1) A description and the principal forms of managerial skills very well belong to the category, as well as the performance of teacher MA Al-Falah Arungkeke Jeneponto classified as either category. This means that managerial skills with ability to approach the conceptual, technical, human relations affect the performance of teacher MA Al-Falah Arungkeke Jeneponto, (2) there is a significant positive implications in terms of principal leadership managerial skills to the improvement of teacher performance MA Al-Falah Arungkeke Jeneponto, this is explained by a score of $70-85 \%$ range, which means simultaneous principal leadership in terms of managerial skills in improving teacher performance MA Al-Falah Arungkeke Jeneponto entry in the category of good value. Based on these results, it is suggested to the principal in general, and a principal in the district in particular to pay attention and improve managerial skills and leadership models and with regard to other factors that affect the performance of teachers. Suggested for teachers to further optimize performance in accordance with the duties and responsibilities.
\end{abstract}

Keywords: Managerial Skill, Teacher's Performance

\section{PENDAHULUAN}

Seiring dengan diberlakukannya otonomi daerah, maka telah terjadi perubahan paradigma dalam pengelolaan pendidikan yang antara lain telah memunculkan suatu model dalam manajemen pendidikan, yaitu school based management. Model manajemen ini pada dasarnya memberikan peluang yang sangat besarkepada sekolah untuk mengelola dirinya sesuai dengan kondisi yang ada serta memberikan kesempatan kepada masyarakat (stakeholders) untuk ikut berpartisipasi aktif dalam penyelenggaraan pendidikan. ${ }^{2}$

Konsekuensi dari pelaksanaan manajemen berbasis sekolah dalam setiap satuan, jenis, dan jenjang pendidikan antara lain sangat diperlukan adanya kemampuan manajerial yang cukup memadai dari kepala sekolah dan didukung oleh adanya kinerja guru yang profesional.

${ }^{1}$ Manajemen Pendidikan Islam Institut Agama Islam Negeri (IAIN) Bone.

${ }^{2}$ Mulyasa, Manajemen Berbasis Sekolah: Konsep, Strategi dan Implementasi (Bandung: RajaGrafindo Persada, 2002), h. 11. 
Konsekuensi ini tentunya dapat juga dilihat dan dirasakan pada penyelenggaraan pendidikan di Madrasah sebagai salah satu lembaga pendidikan formal dalam kerangka sistem pendidikan nasional.

Madrasah merupakan bagian integral dari lembaga pendidikan dalam sistem pendidikan nasional dengan jenjang mulai dari pendidikan dasar (MI dan MTs) hingga pendidikan menengah (MA). Proses penyelenggaran pendidikan di Madrasah pada dasarnya sama dengan penyelenggaraan pendidikan di sekolah yang diselenggarakan oleh departemen pendidikan nasional atau yang lainnya. Madrasah sebagai bagian integral yang tidak terpisahkan dari sistem pendidikan nasional diharapkan mampu mewujudkan manusia Indonesia yang beriman dan bertakwa, serta memiliki kemampuan dan keterampilan yang cukup untuk melanjutkan ke jenjang yang lebih tinggi ataupun untuk terjun ke dalam masyarakat.

Secara fisik kondisi madrasah pada umumnya memiliki banyak kekurangan, baik dalam hal sarana, prasarana, buku-buku maupun fasilitas penunjang pembelajaran serta kekurangan guru, baik secara kualitas maupun kuantitas. Kekurangan tersebut tentunya berakibat pada rendahnya mutu pembelajaran dan outputnya. ${ }^{3}$ Kondisi semacam itu tentunya perlu mendapat perhatian dari pemerintah, khususnya Departemen Agama dan berbagai pihak terkait lainnya. Hal ini dimaksudkan untuk menghargai partisipasi swasta yang telah memberikan sumbangan yang cukup besar dalam ikut serta mencerdaskan bangsa.

Dalam rangka penyelenggaraan pendidikan selanjutnya terutama dalam kaitannya dengan optimalisasi otonomi sekolah/madrasah, paling tidak ada dua aspek penting yang perlu mendapatkan perhatian, yaitu kemampuan manajerial kepala madrasah dan kinerja profesional para gurunya yang ditunjukkan melalui etos kerja yang tinggi.

Dalam dunia pendidikan, maka kinerja guru dapat dilihat dari berbagai tugas yang telah diamanahkan dalam Undang-undang. Pada hakikatnya, kinerja guru bukan hanya sebatas melaksanakan kurikulum sebagai beban kerja, tetapi justeru banyak tugas lain yang harus dilaksanakan dan itu terwujud dalam bentuk kinerja seorang guru. Inilah hakikatnya tuntutan profesionalitas yang telah di sematkan kepada beban dan tanggung jawab kepada mereka. ${ }^{4}$

\footnotetext{
${ }^{3}$ Depag RI, Landasan, Program dan Pengembangan Kurikulum Madrasah Tsanawiyah, (Jakarta: Ditjen Bimbagais, 2002), h. 11.

${ }^{4}$ E. Mulyasa, Menjadi Guru Profesional; Menciptakan Pembelajaran Kreatif dan Menyenangkan, (Jakarta : Rosdakarya, 2008) h.35-65.
} 
Secara inplisit, dalam UU no 20 tahun 2003 dan UU no 14 tahun 2005 telah memberikan gambaran bahwa kinerja guru berada dalam rumusan melaksanakan tugas utama dan menunaikan beban kerja, serta mewujudkan kompetensi dalam mengemban amanah pendidikan yang ada di pundaknya.

Kalau dilihat dalam sudut pandang Islam Kinerja disebut sebagai kesungguhan dan kemauan dalam melaksanakan tugas, hal ini diterangkan dalam firman Allah swt pada Q.S. atTaubah :105, yaitu:

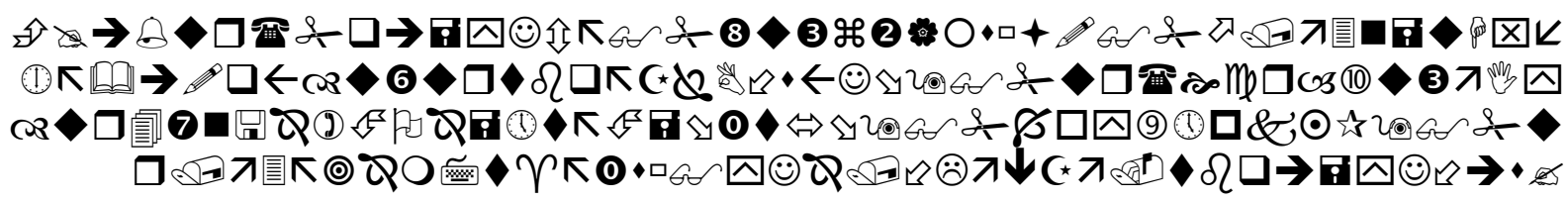
Terjemahnya:

"Dan Katakanlah: "Bekerjalah kamu, Maka Allah dan rasul-Nya serta orangorang mukmin akan melihat pekerjaanmu itu, dan kamu akan dikembalikan kepada (Allah) yang mengetahui akan yang ghaib dan yang nyata, lalu diberitakan-Nya kepada kamu apa yang Telah kamu kerjakan."

Dari Ayat tersebut dapat disimpulkan bahwa pada dasarnya, Islam adalah agama amal atau kerja (praksis), inti ajarannya adalah bahwa seorang hamba itu dekat dan memperoleh ridha dari Allah melalui bekerja atau amal salehnya dan dengan memurnikan sikap penyembahan hanya kepada-Nya. Hal ini juga mengandung makna bahwa Islam adalah agama yang mengajarkan orientasi kerja (achievement orientation), sebagaimana juga dinyatakan dalam ungkapan bahwa "penghargaan dalam Islam berdasarkan amal". Olehnya itu, dalam hidup ini seseorang dianjurkan untuk selalu berbuat baik kepada sesama dan hendaknya mempunyai suatu karya terbaik yang dapat selalu dikenang, dimanfaatkan dan dirasakan oleh semua orang sebagai suatu perwujudan pengabdian diri manusiaterhadap Tuhannya, yang merupakan suatu target dalam hidup didunia untuk mengabdi kepada Allah. ${ }^{6}$

Dari realitas dan pemikiran diatas, maka peneliti tertarik untuk melakukan penelitian disebuah Madrasahyang berjudul "Keterampilan Manajerial Kepala Madrasah dalam meningkatkan Kinerja Guru di Madrasah Aliyah Al-Falah Arungkeke Kabupaten Jeneponto".

\section{A. Metode Penelitian}

Penelitian ini merupakan jenis penelitian kualitatif, yakni mendeskripsikan tentang segala sesuatu yang berkaitan dengan keseluruhan pelaksanaan Manajemen Kepala Madrasah

\footnotetext{
${ }^{5}$ Departemen Agama RI, Al-Quran \& Terjemahnya, (Jakarta: CV. Alwah, 1995), h. 216

${ }^{6}$ Nurcholis Madjid, Spiritualitas Kaum Muda, Sebuah Pembacaan Tematik, (Cet.VII; Jakarta:
} Gramedia, 1995), h. 46-47. 
dalam meningkatkan kinerja guru di Madrasah Aliyah Al-Falah Arungkeke Kabupaten Jeneponto. Untuk mencapai tujuan yang menghasilkan data deskriptif berupa kata-kata tertulis atau lisan dari orang-orang dan perilaku yang dapat diamati dan diarahkan pada latar dan individu tersebut secara menyeluruh.

Metode Pengumpulan data menggunakan Metode Observasi, Metode Angket/Kuisioner, Metode Wawancara(Interview) dan Studi Dokumen sebagai alat yang digunakan untuk mendapatkan informasi yang akurat dan kualitatif tentang pelaksanaan Manajemen Kepala Madrasah dalam meningkatkan kinerja guru di Madrasah Aliyah Al-Falah Arungkeke Kabupaten Jeneponto.

\section{B. Pembahasan}

Berangkat pada masalah dalam penelitian ini, yakni "Keterampilan Manajerial Kepala Madrasah Dalam Meningkatkan Kinerja Guru di Madrasah Aliyah Al-Falah Arungkeke Kabupaten Jeneponto", maka sebagai tindak lanjut untuk mendekati masalah tersebut, berbagai pendapat diramu, berbagai literatur ditelusuri dan ditelaah lalu dijadikan sebagai landasan dan struktur pemikiran dalam penelitian ini.

\section{Keterampilan Manajerial}

Dalam Kamus Inggris-Indonesia karya Echols dan Shadily $^{7}$ disebutkan bahwa keterampilan sepadan dengan kata kecakapan, dan kepandaian yang disebut dengan skill. Sedangkan, manajerial merupakan kata sifat yang berhubungan dengan kepemimpinan dan pengelolaan. Dalam banyak kepustakaan, kata manajerial sering disebut sebagai asal kata dari management yang berarti melatih kuda atau secara harfiah diartikan sebagai to handle yang berarti mengurus, menangani, atau mengendalikan. Sedangkan, management merupakan kata benda yang dapat berarti pengelolaan, tata pimpinan atau ketatalaksanaan. ${ }^{8}$ Pada prinsipnya pengertian manajemen mempunyai beberapa karakteristik sebagai berikut:

a. Ada tujuan yang ingin dicapai;

b. Sebagai perpaduan ilmu dan seni;

c. Merupakan proses yang sistematis, terkoordinasi, koperatif, dan terintegrasi dalam memanfaatkan unsur-unsurnya;

d. Ada dua orang atau lebih yang bekerjasama dalam suatu organisasi;

e. Didasarkan pada pembagian kerja, tugas dan tanggung jawab;

${ }^{7}$ John M. Echols dan Hasan Shadily, Kamus Inggris-Indonesia: An English-Indonesian Dictionary (Jakarta: PT. Gramedia, 1997), h. 530.

${ }^{8}$ Ulbert Silahahi, Studi tentang Ilmu Administrasi: Konsep, Teori, dan Dimensi (Bandung: Sinar Baru Algensindo, 2002), h. 135. 
f. Mencakup beberapa fungsi;

g. Merupakan alat untuk mencapai tujuan. ${ }^{9}$

Deskripsi tugas dan tanggung kepala madrasah dapat dilihat dari dua fungsi, yaitu kepala madrasah sebagai administrator dan sebagai supervisor. ${ }^{10}$ Kepala madrasah sebagai administrator di madrasah mempunyai tugas dan tanggung jawab atas seluruh proses manajerial yang mencakup perencanaan, pengorganisasian, penggerakan, dan pengawasan terhadap seluruh bidang garapan yang menjadi tanggung jawab madrasah. Bidang garapan manajemen tersebut dapat meliputi bidang personalia, siswa, tata usaha, kurikulum, keuangan, sarana dan prasarana, hubungan madrasah dan dengan kegiatan-kegiatan pelayanan terhadap peningkatan kemampuan profesionalisme guru dalam rangka mencapai proses pembelajaran yang berkualitas.

Selain itu, seorang kepala madrasah dalam melaksanakan tugasnya hendaknya mempunyai tiga kecerdasan, yaitu kecerdasan pesonal, kecerdasan profesional, dan kecerdasan manajerial. ${ }^{11}$ Kecerdasan personal adalah kemampuan, skil dan keterampilan untuk melakukan hubungan sosial dalam konteks tata hubungan profesional maupun sosial. Sedangkan, kecerdasan profesional merupakan kecerdasan yang diperoleh melalui pendidikan yang berupa keahlian tertentu di bidangnya. Adapun kecerdasan manajerial adalah kecerdasan yang berkaitan dengan kemampuan untuk melakukan kerja sama dengan mengerjakan sesuatu melalui orang lain, baik kemampuan mencipta, membuat perencanaan, pengorganisasian, komunikasi, memberikan motivasi, maupun melakukan evaluasi.

\section{Kepemimpinan Madrasah}

Manusia merupakan makhluk sosial (al-kiyan al-ijtima'i) yang diciptakan untuk berhubungan satu dengan yang lain, dalam mencapai tujuan hidupnya. Dalam berhubungan satu sama lain, diperlukan adanya seorang pemimpin yang melaksanakan, memandu, dan membawa pekerjaan ke arah pencapaian tujuan, demi terwujudnya kebaikan dan reformasi. ${ }^{12}$

Di antara jenis kepemimpinan adalah kepemimpinan pendidikan (qiyadah tarbawiyah atau educative leadership), karena keberhasilan pendidikan dalam membina umat dan berusaha membangkitkannya erat kaitannya dengan figur kepemimpinan pendidikan yang

\section{3}

${ }^{9}$ Malayu SP. Hasibuan, Manajemen: Dasar, Pengertian, dan Masalah (Jakarta: Bumi Aksara, 2001), h.

${ }^{10}$ Ngalim Purwanto, Administrasi dan Supervisi Pendidikan, Bandung: Penerbit PT. Remaja Rosdakarya, 1998). h.106.

${ }^{11}$ Dede Rosyada, Paradigma Pendidikan Demokratis: Sebuah Model Pelibatan Masyarakat dalam Penyelenggaraan Pendidikan, (Jakarta: Kencana, 2004), h. 239

${ }^{12}$ Nanang Fatchurochman, Madrasah Sekolah Islam Terpadu, Plus dan Unggulan, (Depok; Lentera Hati Pustaka, 2012), h. 21. 
benar. Krisis yang melanda masyarakat akhir-akhir ini tiada lain hilangnya murabbi (pendidik) yang teladan atau pemimpin tarbawi. ${ }^{13}$

Berbagai perubahan masyarakat dan krisis multidimensional yang sedang melanda Indonesia akhir-akhir ini, antara lain ditandai dengan sulitnya menemukan sosok pemimpin idealis yang memiliki komitmen tinggi terhadap pendidikan. Kepemimpinan merupakan hal yang sangat penting dalam manajemen berbasis madrasah. Kepemimpinan berkaitan dengan masalah kepala madrasah dalam meningkatkan kesempatan untuk mengadakan pertemuan dengan seluruh stakeholder madrasah lainnya dalam situasi yang kondusif. Perilaku pemimpin yang positif dapat mendorong kelompok dalam mengarahkan dan memotivasi individu untuk bekerjasama dalam kelompok guna mewujudkan tujuan madrasah. ${ }^{14}$

Seorang kepala madrasah harus mempunyai nilai kemampuan relation yang baik dengan segenap stakeholder madrasah, sehingga tujuan madrasah dan tujuan pendidikan berhasil dengan optimal. Ibarat nahkoda yang menjalankan sebuah kapal mengarungi samudera, kepala madrasah mengatur segala sesuatu yang ada di madrasah. Dalam Alquran telah terdapat nilai-nilai agung tentang arti pentingnya kepemimpinan. Salah satu pesan-pesan agung tentang kepemimpinan dari firman Allah swt pada Q.S. As-Sajadah ayat 24 yakni:

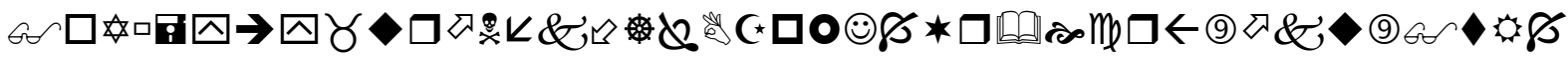

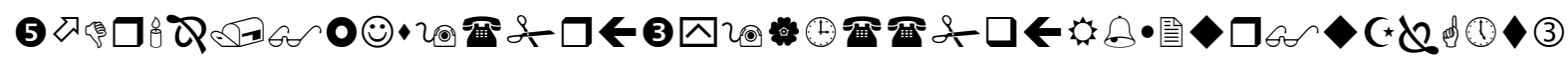

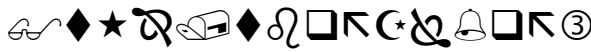

Terjemahnya:

"Dan kami jadikan di antara mereka itu pemimpin-pemimpin yang memberi petunjuk dengan perintah kami ketika mereka sabar dan adalah mereka meyakini ayat-ayat kami"15

Demikian pula pada sabda Rasulullah saw yakni:...

$$
\begin{aligned}
& \text { عن عبدالله بن عمررضي الله عنهما: ان رسول الله صلي الله عليه وسلم قال: كلكم راع وكلكم مسؤول عن رعيته فالأمام } \\
& \text { الاعظم الذي على الناس راع و هو مسؤول عن رعيته و الرجل راع على اهل بيته وهو مسؤول عن رعيته و المر أة راعية } \\
& \text { على أهل بيت زوجهاوولده وهي مسؤولة عنهم و عبدالرجل راع على مال سيده وهومسؤول عنه ألافكلكم راع وكلكم } \\
& \text { مسؤول عن رعيته . }
\end{aligned}
$$

Terjemahnya:

\footnotetext{
${ }^{13}$ Ibid., h. 22.

${ }^{14}$ Sri Minarti, Manajemen Madrasah, Mengelola Lembaga Pendidikan secara Mandiri, (Yogyakarta: Ar-Ruazz, 2011), h. 85.

${ }^{15}$ Departemen Agama RI, Al-Quran \& Terjemahnya, (Jakarta: CV. Alwah, 1995), h. 589.
} 
"Dari 'Abdullah bin Umar r.a. berkata bahwa Rasulullah saw telah bersabda "Ketauhilah: setiap pemimpin dimintai pertanggung-jawaban atas apa yang dipimpin, setiap imam dimintai pertanggung-jawabannya, setiap laki-laki menjadi pemelihara dalam keluarganya (anak-anak, isteri dan lain-lain), dan bertanggungjawab terhadap (baik-buruknya) pemeliharaannya itu, setiap wanita dimintai pertanggungjawabannya terhadap rumah suaminya dan persoalan di dalamnya, setiap hamba bertanggung jawab atas harta tuannya dan setiap persoalan dimintai pertanggung-jawaban"16

Dari firman Allah swt dan sabda rasul-Nya ini tersirat jelas sebuah makna filosofis yang mendalam bahwa menjadi pemimpin itu termasuk memimpin dalam konteks lembaga pendidikan Islam (madrasah) harus mengutamakan sifat sabar. Kesabaran yang dimaksud adalah kesabaran dalam menegakkan kebenaran.

Disamping itu pesan moral dari dua dalil tersebut menegaskan bahwa seorang pemimpin atau khalifah fil ardi yang mana kepemimpinan itu akan kita pertanggung jawabkan di akhirat kelak, seorang pemimpin harus mempunyai beberapa sifat yang ada dalam ketauladan pada Nabi kita Muhammad SAW, seorang pemimpin yang muslim dan mu'min harus mempunyai 4 (empat) sifat utama kekuatan akhlaq Rasul dan Nabi kita Muhammad SAW yaitu:

a. Siddiq; Seorang pemimpin dalam Islam harus mempunyai sifat Siddiq yang berarti jujur, mempunyai integritas yang tinggi dan selalu berusaha untuk tidak berbuat suatu kesalahan yang dapat menghilangkan rasa kepercayaan ummat atau kaumnya terhadapnya.

b. Tabligh; Pemimpin harus selalu menyampaikan tentang kebenaran yang seharusnya disampaikan kepada orang yang dipimpinnya. Dia harus komunikatif dan tidak boleh menyembunyikan hal-hal yang seharusnya disampikan.

c. Amanah; Berarti dapat dipercaya. Dapat dipercaya dalam setiap perkataan atau pun dalam setiap perbuatannya. Pemimpin yang baik dalam Islam harus selalu Istiqomah dalam mengemban amanahnya.

d. Fathonah; Berarti cerdas, mempunyai pengetahuan/intelektual yang tinggi dan selalu bersikap professional dalam menghadapi setiap masalah. ${ }^{17}$

\footnotetext{
${ }^{16} \mathrm{Abu}$ Abdillah Muhammad Ibn Ismail al-Bukhari, al-Jami' al-Sahih al-Musnad min Hadits Rasulullah Sallallahu 'alaihi wa Sallam wa Ayyamihi, Jil.III, (Kairo: al-Matba'ah al-Salafiyah, 1403 H), h.328.

${ }^{17}$ Kartini Kartono, Pemimpin dan Kepemimpinan,(Cet.IV; Jakarta: Rajawali Press, 1993), h.14.
} 
Empat hal tersebut merupakan sifat-sifat yang seharusnya dimiliki oleh seorang pemimpin Islam dalam menjalankan tugasnya sebagai khalifah Allah SWT di dunia ini secara menyambung satu sifat dengan sifat lainnya karena dari keempat sifat tersebut tidak akan terwujud seorang pemimpin yang diidam-idamkan oleh masyarakat jika ada salah satu sifat tidak ada dalam diri seorang pemimpin, baik dia sebagai pemimpin keluarga, sampai menjadi seorang pemimpin madrasah.

\section{Kinerja Guru}

Pendidik adalah orang dewasa yang bertanggung jawab memberi bimbingan atau bantuan kepada anak didik dalam perkembangan jasmani dan rohaninya agar mencapai kedewasaannya, mampu melaksanakan tugasnya sebagai makhluk Allah, khalifah di permukaan bumi, sebagai makhluk sosial dan sebagai individu yang sanggup berdiri sendiri. ${ }^{18}$

Istilah lain yang lazim dipergunakan untuk pendidik ialah guru. Kedua istilah tersebut bersesuaian artinya, bedanya ialah istilah guru seringkali dipakai di lingkungan pendidikan formal, sedangkan pendidikan dipakai di lingkungan formal, informal maupun non formal. ${ }^{19}$

Tugas guru sebagai suatu profesi menuntut kepada guru untuk mengembangkan profesionalitas diri sesuai perkembangan ilmu pengetahuan dan teknologi. Mendidik, mengajar, dan melatih anak didik adalah tugas guru sebagai suatu profesi. Tugas guru sebagai pendidik berarti meneruskan dan mengembangkan nilai-nilai hidup kepada anak didik. Tugas guru sebagai pengajar berarti meneruskan dan mengembangkan ilmu pengetahuan dan teknologi kepada anak didik. Tugas guru sebagai pelatih berarti mengembangkan keterampilan dan menerapkannya dalam kehidupan demi masa depan anak didik.

Untuk melaksanakan tugas dan tanggung jawab tersebut seorang guru harus memiliki moral kerja yang tinggi. Seorang guru dituntut memiliki kedisiplinan yang tinggi, ia harus datang tepat pada waktunya untuk mengajar dan pulang tepat pada waktunya pula, tidak boleh menyia-nyiakan waktu mengajarnya dengan kegiatan-kegiatan lain yang tidak relevan dengan tugas mengajarnya. Sebagai seorang guru, ia harus mampu mengajar dengan tenang sehingga dapat menyampaikan materi pelajaran secara sistematis dan mudah dipahami oleh semua murid, ia harus mengajar dengan penuh antusias, kegembiraan, dan penuh gairah, sebab yang demikian ini akan menimbulkan daya tarik tersendiri bagi murid-muridnya. ${ }^{20}$

\footnotetext{
${ }^{18}$ Nur Uhbiyati, Ilmu Pendidikan Islam (IPI) Jilid I, (Bandung: CV Pustaka Setia, 1998), h.65.

${ }^{19}$ Ibid

${ }^{20} \mathrm{Ibid}$
} 
Guru adalah figur seorang pemimpin. Guru adalah sosok arsitekturyang dapat membentuk jiwa dan watak anak didik. Guru mempunyaikekuasaan untuk membentuk dan membangun kepribadian anak didik menjadiseorang yang berguna bagi agama, nusa, dan bangsa. Guru bertugasmempersiapkan manusia susila yang cakap yang dapat diharapkan membangun dirinya dan membangun bangsa dan negara. ${ }^{21}$

Seorang kepala madrasah, di samping harus mampu melaksanakan proses manajemen yang merujuk pada fungsi-fungsi manajemen, juga dituntut untuk memahami sekaligus menerapkan seluruh substansi kegiatan pendidikan. Olehnya itu, kepala madrasah dituntut untuk memiliki kemampuan: (1) Menjabarkan sumber daya sekolah untuk mendukung pelaksanaan proses belajar mengajar, (2) kepala administrasi, (3) sebagai manajer perencanaan dan pemimpin pengajaran, dan (4) mempunyai tugas untuk mengatur, mengorganisir dan memimpin keseluruhan pelaksanaan tugas-tugas pendidikan di madrasah.

Kepala madrasah bertugas untuk membangun manajemen madrasah serta bertanggungjawab dalam pelaksanaan keputusan manajemen dan kebijakan madrasah. Untuk mencapai hal itu maka seorang kepala madrasah minimal memiliki pengetahuan dan keterampilan dalam bidang keadministrasian sekolah; keterampilan hubungan manusiawi dengan staf, guru, siswa dan masyarakat, serta keterampilan teknis instruksional dan noninstruksional.

Kepala Madrasah merupakan manajer yang wajib memiliki kesadaran dan kepekaan budaya sebagai bagian dari keterampilannya, di mana seorang manajer dituntut untuk dapat menghargai nilai keberagaman kultur yang ada di dalam organisasinya. Kepala madrasah selaku manajer di madrasah sangat mungkin akan dihadapkan dengan warga madrasah, dengan latar kultur yang beragam, baik guru, tenaga administrasi maupun siswa. Oleh karenanya, kepala madrasah dituntut untuk dapat menghargai keberagaman kultur ini.

Jika kacamata objektif unsur Pimpinan Madrasah dan para Guru dalam melihat pentingnya keterampilan manajerial dari sosok kepala madrasah dalam upaya membawa madrasah menjadi center of excellence, pusat keunggulan dalam mencetak dan mengembangkan sumberdaya manusia madrasah, maka hasilnya dapat dilihat dari Tabel berikut:

${ }^{21}$ Syaiful Bahri Djamarah, Guru dan Anak Didik dalam Interaksi Edukatif, (Jakarta: Rineka Cipta, 
Tabel 1

Pandangan Unsur Pimpinan dan Guru terhadap Pentingnya Keterampilan Manajerial

\begin{tabular}{|c|c|c|c|}
\hline No & Kategori Jawaban & Frekuensi (F) & Presentase (\%) \\
\hline 1 & Sangat Penting & 12 & $80 \%$ \\
2 & Penting & 3 & $20 \%$ \\
3 & Kurang Penting & 0 & 0 \\
4 & Tidak Penting & 0 & 0 \\
\hline & Jumlah & $\mathbf{1 5}$ & $\mathbf{1 0 0}$ \\
\hline
\end{tabular}

Sumber Data: Hasil Olahan Angket No.1

Dari tabel di atas, menunjukkan bahwa 12 responden atau $80 \%$ yang menjawab sangat penting Keterampilan Manajerial yang dimiliki pimpinan pada lingkup MA Al-Falah Arungkeke Kabupaten Jeneponto, dan 3 responden atau $20 \%$ yang menjawab penting, dan yang menjawab kurang penting dan tidak penting sebanyak 0 atau $0 \%$.

Dari keterangan di atas, dapat di deskripsikan berdasarkan analisis bahwa frekuensi tertinggi adalah $80 \%$ atau 12 responden yang menganggap bahwa keterampilan manajerial yang dimiliki pimpinan sangat penting bagi kalangan stakeholder MA Al-Falah Arungkeke Kabupaten Jeneponto. Hal ini didukung pula dari hasil wawancara yang dilakukan dengan seorang guru, St.Kumala, S.Pd, yang berkomentar bahwa "Pimpinan Madrasah atau Kepala Madrasah dituntut membuat perencanaan, mengorganisir, memimpin, memotivasi, mengendalikan dan mengevaluasi seluruh sumber daya yang ada dimadrasah sebab hal itu merupakan hal penting dan strategis dalam upaya pencapaian kemajuan suatu madrasah". ${ }^{22}$

Hasil wawancara tersebut di atas, menunjukkan jika kepala madrasah dapat mengoptimalkan peran dan kemampuannya sebagai pemimpin bagi seluruh stakeholder MA Al-Falah Arungkeke Kabupaten Jeneponto khususnya para guru, maka hal tersebut akan memberi implikasi positif dalam peningkatan kinerja guru.

Demikian pula dengan Muh. Rusli, S.PdI (Wakil Kepala Madrasah), yang mengemukakan bahwa "kepala madrasah idealnya mampu melakukan kerja sama dengan mengerjakan sesuatu melalui orang lain, baik kemampuanmembuat perencanaan, pengorganisasian, komunikasi, memberikan motivasi, maupun melakukan evaluasi. Hal

${ }^{22}$ St.Kumala, Guru, Wawancara, di MA Al-Falah Arungkeke Jeneponto. 
tersebut penting mengingat madrasah sekarang mempunyai wewenang untuk mengatur dan mengelola dirinya sendiri, inilah yang disebut dengan desentralisasi pendidikan. Dengan demikian, dalam kerangka pelaksanaan otonomisasi pendidikan khususnya di madrasah, paling tidak yang perlu mendapatkan perhatian secara signifikan yaitu kemampuan manajerial kepala madrasah itu sendiri.". ${ }^{23}$

Hasil wawancara tersebut dapat dibuktikan bahwa jawaban yang menyatakan sangat pentingnya ketarampilan manajerial pimpinan di MA Al-Falah Arungkeke Kabupaten Jeneponto cukup beralasan. Hal ini dinilai dari 12 responden masing menginginkan adanya keseriusan serta perhatian dalam memaksimalkan keterampilan manajerial tersebut bagi para stakeholder madrasah khususnya bagi para guru dalam upaya meningkatkan kinerjanya masing-masing.

Untuk dapat mencapai keunggulan dan kualitas institusi, diperlukan kemampuan manajerial kepala madrasah yang memadai sehingga dapat memimpin dan menggerakkan semangat kerja dan performance para guru dan seluruh komponen madrasah secara lebih optimal.

Dalam pendekatan praktis, bila keterampilan manajerial pimpinan madrasah berjalan dengan baik, maka akan menghasilkan pula manfaat bagi madrasah pada umumnya dan secara personalitas dari tiap komponen pada khususnya. Adapun manfaat keterampilan manajerial bagi lingkungan madrasah pada umumnya serta bagi peningkatan kinerja para guru pada khususnya dapat disimak pada deskripsi tabel berikut:

Tabel 2

Pandangan Unsur Pimpinan, dan Guru terhadapmanfaat Keterampilan Manajerial bagi Lingkungan Madrasah

\begin{tabular}{|c|c|c|c|}
\hline No & Kategori Jawaban & Frekuensi (F) & Presentase (\%) \\
\hline 1 & Sangat Bermanfaat & 14 & $94 \%$ \\
2 & Bermanfaat & 1 & $6 \%$ \\
3 & Kurang Bermanfaat & 0 & 0 \\
4 & Tidak Bermanfaat & 0 & 0 \\
\hline & Jumlah & $\mathbf{1 5}$ & $\mathbf{1 0 0}$ \\
\hline
\end{tabular}

Sumber Data: Hasil Olahan Angket No.2

Dari tabel di atas, menunjukkan bahwa terdapat 14 responden atau $94 \%$ yang menjawab sangat bermanfaat keterampilan manajerial pimpinan madrasah bagi stakeholder

\footnotetext{
${ }^{23}$ Muh. Rusli, S.PdI, Guru, Wawancara, di MA Al-Falah Arungkeke Jeneponto.
} 
madrasah khususnya lagi bagi para guru. Sedangkan untuk kategori jawaban bermanfaat, maka hanya terdapat 1 responden atau $6 \%$ saja.Dan adapun yang menjawab kurang bermanfaat dan tidak bermanfaat sebanyak 0 atau $0 \%$.

Berdasarkan keterangan tersebut, maka responden lebih cenderung menyatakan bahwa keterampilan manajerial pimpinan madrasah sangat bermanfaat. Hal ini menandakan bahwa keterampilan manajerial pimpinan madrasah sangat urgen untuk direalisasikan dan ditingkatkan tidak hanya untuk para guru melainkan pula bagi seluruh komponen madrasah.

Salah seorang guru yang bernama Nuraeni, S.PdI, guru Fiqih, yang menyatakan bahwa salah satu manfaat positif yang terlihat di lingkungan madrasah manakala keterampilan manajerial pimpinan madrasah direalisasikan dengan baik yakni akan menjadikan sumberdaya manusia (SDM) di madrasah khususnya para guru mampu melaksanakan tugas-tugas kependidikan secara efektif." 24

Lebih jauh dalam pandangan Ibu Nuraeni tersebut di atas, keterampilan manajerial kepala madrasah sebagai pengelola pendidikan memiliki tugas mengembangkan kinerja para guru dan pegawai, menjadi guru dan pegawai yang profesional. Dengan kata lain dalam perspektif kemadrasahan, kepala madrasah diharuskan memiliki keterampilan untuk mengembangkan seluruh sumber daya manusia yang tersedia di madrasahnya, agar mereka menjadi berdaya dan memberikan kontribusi untuk meningkatkan kualitas madrasahnya.

Olehnya itu, penting serta bermanfaatnya keterampilan manajerial kepala madrasah di MA Al-Falah Arungkeke, maka sedikit banyaknya akan memberi implikasi positif pada kemampuan mengajar para guru dan stakeholder madrasah lainnya. Sebuah madrasah yang dikelola dengan sistem manajerial yang baik dan profesional tentu sangat berbeda dengan madrasah yang pengelolaannya serampangan dan biasa-biasa saja.

Adapun pandangan para stakeholder MA Al-Falah Arungkeke Kabupaten Jeneponto terhadap adanya perbedaan antara madrasah yang dikelola dengan manajemen yang baik dengan madrasah yang kurang baik manajemennya, dapat dilihat pada tabel berikut: 
Tabel 3

Pandangan Unsur Pimpinan, Guru \& Siswa terhadap Perbedaan Madrasahdengan Manajemen yang baik dengan Madrasah yang Manajemennya kurang Baik

\begin{tabular}{|c|c|c|c|}
\hline No & Kategori Jawaban & Frekuensi (F) & Presentase $(\%)$ \\
\hline 1 & Sangat Berbeda & 132 & 97,8 \\
\hline 2 & Berbeda & 3 & 2,2 \\
\hline 3 & Biasa-Biasa Saja & 0 & 0 \\
\hline 4 & Tidak Ada Perbedaan & 0 & 0 \\
\hline \multicolumn{2}{|r|}{ Jumlah } & 135 & 100 \\
\hline
\end{tabular}

Sumber Data: Hasil Olahan Angket No.3

Berdasarkan tabel di atas, maka diketahui bahwa 132 responden atau 97,8 \% yang menjawab sangat berbeda bila madrasah dikelola dengan manajemen yang baik, 3 responden atau 2,2 \% yang menjawab berbeda, dan yang menjawab biasa-biasa saja serta tidak ada perbedaan sebanyak 0 atau $0 \%$.

Berangkat dari keterangan itu menunjukkan secara gamblang bahwa responden masih menyatakan sangat berbeda dalam melihat adanya perbedaan antara sebuah madrasah yang dikelola dengan manajemen yang baik serta profesional dengan yang tidak. Hal ini adalah kecenderungan positif dan dapat diartikan bahwa mayoritas komponen madrasah masih menginginkan madrasahnya dikelola dengan sistem manajemen yang baik yang ditandai dengan kemampuan pimpinan madrasah dalam mengorganisasi dan mengembangkan sumber daya madrasah untuk menciptakan lingkungan belajar yang efektif dan efisien.

Rusli, S.Hum., kepala tata usaha, responden dalam penelitian ini mengemukakan bahwa "lembaga pendidikan yang senantiasa mampu menyeimbangkan antara kemampuan kepemimpinan yang berorientasi manajerial dengan kepemimpinan yang berorientasi humanis akan sangat berbeda dengan lembaga pendidikan lainnya yang kurang memperhatikan tentunya. Contoh perbedaan yang paling dapat dirasakan adalah dari interaksi sinergis keduanya melahirkan suasana kepemimpinan ideal, yaitu mampu membawa organisasi madrasah untuk mencapai tujuan secara efektif dan efisien". ${ }^{25}$

\footnotetext{
${ }^{25}$ Rusli, S.Hum, Guru, Wawancara, di MA Al-Falah Arungkeke Jeneponto.
} 
Ditambahkan lagi oleh pendapat seorang siswa, Nita Almasyah Dewi, yang berkata bahwa "meskipun madrasah ini berada di wilayah desa dalam kabupaten jeneponto, namun sebagai siswa kami sangat menginginkan sistem manajemen yang diterapkan oleh pimpinan madrasah khususnya para guru tidak kalah dengan manajemen di lembaga pendidikan lain yang berada di kota-kota besar. Olehnya itu, memang sudah saatnya pimpinan madrasah membenahi beberapa hal yang terkait dengan pelayanan kepada seluruh pihak dalam madrasah ini, agar kami sebagai sebagai siswa dapat belajar dengan semangat dan berprestasi tentunya." 26

Berangkat dari wawancara dan fakta responden tersebut di atas, menunjukkan bahwa terdapat perbedaan antara madrasah yang dikelola dengan sistem manajemen yang baik dengan madrasah yang kurang baik manajemennya. Hal itu terlihat dari kuatnya keinginan dari semua stakeholder MA Al-Falah Arungkeke Kabupaten Jeneponto untuk lebih mengoptimalkan sistem manajemen khususnya manajemen kepemimpinan dari kepala madrasah. Dan hal ini dapat dilakukan oleh pihak madrasah agar ke depan mampu mendesain sistem manajemen yang baik dan minimal mampu memberi efek positif terhadap peningkatan kinerja para pegawai, guru dan mengangkat prestasi siswa.

Dengan demikian, pernyataan 132 responden yang menyatakan sangat berbeda antara madrasah yang dikelola dengan sistem manajerial yang baik dengan yang kurang baik, cukup beralasan karena menganggap bahwa dengan memperhatikan dan mengoptimalkan perangkat dan kebutuhan manajemen dalam lingkup madrasah, maka sedikit banyaknya akan mempengaruhi tingkat produtifitas kerja pegawai/guru dan prestasi siswa.

Selanjutnya, dalam rangka penyelenggaraan pendidikan yang berkesinambungan terutama dalam kaitannya dengan optimalisasi otonomi madrasah, paling tidak ada dua aspek penting yang perlu mendapatkan perhatian, yaitu kemampuan manajerial kepala madrasah dan kinerja profesional para gurunya.

Pertama, kemampuan (skill) kepala madrasah dalam membuat perencanaan, mengorganisir, memimpin, memotivasi, mengendalikan dan mengevaluasi seluruh sumber daya yang ada di madrasah merupakan hal penting dan strategis dalam upaya pencapaian kemajuan suatu madrasah. Madrasah sebagai suatu sistem sosial, mempunyai dimensi yang sangat kompleks sehingga tidak dapat terlepas dari berbagai permasalahan yang menuntut adanya pemecahan yang komprehensif dan dapat diterima oleh semua pihak. Oleh sebab itu, diperlukan upaya mengembangkan kemampuan manajerial yang memadai sehingga 
diharapkan dapat terwujud kondisi madrasah yang dinamis dan kondusif dalam rangka meningkatkan kualitas madrasah yang bersangkutan.

Namun, hingga saat ini penguasaan konsep administrasi dan manajerial serta regulasi-regulasi yang relevan dengan tugas kependidikan madrasah tampaknya belum banyak dipahami oleh banyak kepala madrasah. Mereka cenderung bekerja secara apa adanya dengan mengandalkan pengalaman mereka sejak diangkat menjadi guru, wali kelas, dan pembantu kepala madrasah hingga diangkat menjadi kepala madrasah. Selain itu, banyak di antara mereka yang karena tidak dipersiapkan secara khusus, maka pemahaman terhadap perubahan yang terjadi di luar sistem pendidikan sangatlah rendah sehingga akhirnya kemampuan untuk memotivasi dan mengatur bawahan juga menjadi sangat minim, dan hal ini berimplikasi terhadap kinerja para guru.

Dalam kaitannya dengan penelitian ini, maka untuk mengukur tingkat kapasitas para guru terhadap kinerjanya di MA AlFalah Arungkeke Kabupaten Jeneponto, maka salah satunya ialah dengan bagaimana melihat pada aspek eksternal guru itu sendiri. Misalnya, sejauh mana pimpinan madrasah menjalankan sistem manajemen yang profesional untuk ditransformasikan ke para guru. Berikut ini dekripsi faktual MA Al-Falah Arungkeke Kabupaten Jeneponto terkait dengan komitmen pengembangan kemampuan manajerial pimpinan madrasah dan kinerja para gurunya.

\section{Tabel 4}

Pandangan Pimpinan Sekolah, Guru, dan Siswa terhadap Perlunya mengembangkan Kemampuan Manajerial Pimpinan Madrasah dan Kinerja Guru di MA Al-Falah Arungkeke Kabupaten Jeneponto

\begin{tabular}{|c|c|c|c|}
\hline No & Kategori Jawaban & Frekuensi (F) & Presentase $(\%)$ \\
\hline 1 & Sangat Perlu & 87 & 64,4 \\
\hline 2 & Perlu & 48 & 35,6 \\
\hline 3 & Kurang Perlu & 0 & 0 \\
\hline 4 & Tidak Perlu & 0 & 0 \\
\hline \multicolumn{2}{|r|}{ Jumlah } & 135 & 100 \\
\hline
\end{tabular}

Sumber Data: Hasil Olahan Angket No.5

Dari tabel di atas, menunjukkan bahwa 87 responden atau 64,4\% yang menjawab sangat perlu mengembangkan kemampuan manajerial pimpinan madrasah dan inipun berbanding lurus dengan keinginan untuk mengembangkan kinerja guru di lingkup MA AlFalah Arungkeke Kabupaten Jeneponto, 48 responden atau 35,6 \% yang menjawab perlu 
pengembangan kemampuan manajerial pimpinan madrasah, dan untuk kategori jawaban kurang perlu dan tidak perlu sebanyak 0 atau $0 \%$.

Keterangan di atas menunjukkan pula bahwa responden pada pertanyaan ini tidak lagi signfikan menjawab kategori jawaban "sangat perlu" sama dengan jawaban-jawaban pada pertanyaan sebelumnya. Dengan kata lain, responden tidak lagi seantusias menjawab urgen untuk pertanyaan yang berkaitan dengan komitmen pengembangan kemampuan manajerial pimpinan madrasah dan kinerja guru. Setelah penulis mengadakan pemutakhiran data dengan cermat, maka didapatlah jawaban, bahwa rata-rata responden yang memilih kategori jawaban "perlu" adalah sebagian besar dari unsur guru dan sebagian kecil lagi dari unsur pimpinan MA Al-Falah Arungkeke Kabupaten Jeneponto sendiri.

Hal ini dapat diketahui jawabannya, setelah peneliti mendapatkan pandangan dan statemen dari salah seorang guru bernama, Adriyana, SE yang mengemukakan bahwa "pada dasarnya kepala madrasah sebagai pengelola lembaga pendidikan memiliki tugas mengembangkan kinerja personel, terutama meningkatkan profesionalisme kerja guru. Yang kami maksudkan dengan profesionalisme kerja di sini, tidak hanya berkaitan dengan penguasaan materi semata, tetapi mencakup seluruh jenis dan isi kandungan kerjanya."27

Jika dianalisa pernyataan dari salah seorang guru tersebut di atas, maka dapat dikatakan bahwa seakan ada semacam ketakutan/kekhawatiran dari kalangan madrasah utamanya guru manakala sistem manajemen yang diterapkan oleh pimpinan madrasah tidak bermuara dan berbanding lurus dengan pengembangan kinerja guru. Meskipun secara umum mereka tidak menolak dan bahkan menganjurkan juga pengembangan kapasitas personalia para pimpinan madrasah yang berorientasi pada pengembangan stakeholder dan bidang lainnya dalam lingkup madrasah MA Al-Falah Arungkeke.

Namun, ada pula pandangan yang cukup menarik dari salah seorang guru yang bernama Muh. Husni Syam, S.PdI, yang mengemukakan bahwa "pengembangan keterampilan manajerial pimpinan yang terjawantah tiga aspek kemampuan yakni kemampuan konseptual, kemampuan hubungan manusia, dan kemampuan teknik, laksana sebuah pelangi yang mengelilingi sebagian sisi langit. Sistem yang diterapkan akan menjadi payung serta landasan dalam menggerakkan roda organisasi madrasah dan stimulator bagi program kerja para guru. Olehnya itu, pengembangan tersebut harus segera direalisasikan dan dimanifestasikan dalam tata kelola madrasah ini". ${ }^{28}$

\footnotetext{
${ }^{27}$ Adriyana, Guru, Wawancara, di MA Al-Falah Arungkeke Jeneponto.

${ }^{28}$ Muh. Husni Syam, S.PdI, Guru, Wawancara, di MA Al-Falah Arungkeke Jeneponto.
} 
Jika demikian, maka pernyataan 87 responden yang menyatakan sangat perlu pengembangan keterampilan manajerial pimpinan madrasah dan kinerja guru yang menjadi orientasinya dalam lingkup MA Al-Falah Arungkeke Kabupaten Jeneponto, cukup beralasan karena menganggap bahwa dengan pengembangan itulah nantinya akan menjadi stimulus bagi para guru untuk mengadakan umpan balik terhadap berbagai hal, kemampuan, ketelitian, kekurangan dan potensinya yang pada gilirannya bermanfaat untuk menentukan tujuan, jalur, rencana, dan pengembangan karirnya. Bagi madrasah, pengembangan ini akan sangat penting dalam mengambil keputusan berbagai hal, seperti identifikasi kebutuhan program madrasah, penerimaan, pemilihan, pengenalan, penempatan, promosi, sistem imbalan dan aspek lain dari keseluruhan proses pengembangan sumber daya manusia secara keseluruhan.

Dalam memberdayakan masyarakat dan lingkungan sekitar, kepala madrasah merupakan kunci keberhasilan yang harus menaruh perhatian tentang apa yang terjadi pada peserta didik di madrasah dan apa yang dipikirkan orang tua dan masyarakat tentang madrasah. Kepala madrasah dituntut untuk senantiasa berusaha membina dan mengembangkan hubungan kerja sama yang baik antara madrasah dan masyarakat guna mewujudkan madrasah yang efektif dan efisien. Hubungan yang harmonis ini akan membentuk beberapa sikap, yakni: 1) saling pengertian antara madrasah, orang tua,masyarakat, dan lembaga-lembaga lain yang ada di masyarakat, termasuk dunia kerja; 2) saling membantu antara madrasah dan masyarakat karena mengetahui manfaat, arti dan pentingnya peranan masing-masing; 3) kerjasama yang erat antara madrasah dengan berbagai pihak yang ada dimasyarakat dan mereka merasa ikut bertanggung jawab atas suksesnya pendidikan di madrasah.

Untuk merealisasikan ketiga poin tersebut di atas, maka salah satu agen utama madrasah yang berperan memberikan edukasi ke tengah-tengah masyarakat adalah guru itu sendiri. Sebab tugas lain dari guru adalah mediator antara madrasah dan masyarakat. Yang perlu ditekankan di sini adalah bagaimana seorang guru mampu tampil menjadi pribadi mandiri, kreatif, inovatif dalam menjalankan tugasnya tanpa harus tergantung kepada pimpinan atau pemerintah. Olehnya itu, jauh sebelumnya seorang guru wajib mengembangkan profesionalitas diri sesuai perkembangan ilmu pengetahuan dan teknologi.

Mendidik, mengajar, dan melatih anak didik adalah tugas guru sebagai suatu profesi. Tugas guru sebagai pendidik berarti meneruskan dan mengembangkan nilai-nilai hidup kepada anak didik. Tugas guru sebagai pengajar berarti meneruskan dan mengembangkan ilmu pengetahuan dan teknologi kepada anak didik. Tugas guru sebagai pelatih berarti 
mengembangkan keterampilan dan menerapkannya dalam kehidupan demi masa depan anak didik. $^{29}$

Di sinilah pentingnya kepala madrasah profesional tampil sebagai figur yang harus mampu memimpin tenaga kependidikan di madrasah, agar tidak hanya meningkatkan kinerjanya saja, melainkan mampu bekerja sama dengan orang tua dan masyarakat pada umumnya. Karena itulah, kepala madrasah dituntut untuk mampu menciptakan iklim yang kondusif demi tercapainya tujuan pendidikan yang di cita-citakan.

Kepala madrasah yang profesional adalah pemimpin yang memiliki keterampilan manajerial yang baik. Menurut Dra. Mottiara, guru, bahwa pimpinan madrasah atau pimpinan lembaga pendidikan di mana pun juga harus memiliki kemampuan dasar salah satunya adalah kemampuan konseptual yang memadai. Kemampuan konseptual yang dimaksud adalah kemampuan mental untuk mengkoordinasikan, dan memadukan semua kepentingan serta kegiatan organisasi. Dengan kata lain, kemampuan konseptual ini terkait dengan kemampuan untuk membuat konsep (working with ideas) tentang berbagai hal dalam madrasah yang dipimpinnya." $" 30$

Seiring dengan perubahan paradigma desentralisasi pendidikan dan otonomisasi madrasah dengan diberlakukannya suatu model manajemen school based management, maka kepala madrasah sebagai top manajemen di madrasah mempunyai kedudukan yang sangat penting dan strategis. Bahkan keberhasilan suatu madrasah sangat ditentukan oleh kemampuan kepala madrasah dalam mengelola dan memimpin lembaganya.

Dalam kaitannya dengan pengembangan personalia di madrasah, menurut Wiles sebagaimana ditulis oleh Sahertian bahwa ada sejumlah keterampilan yang perlu dimiliki oleh seorang pemimpin pendidikan yaitu keterampilan dalam memimpin, menjalin hubungan kerja dengan sesama, menguasai kelompok, mengelola administrasi personalia, dan keterampilan dalam penilaian. ${ }^{31}$

Ditambahkan pula oleh Sumaryanto, S.PdI, wakil kepala madrasah, bahwa sebagai pimpinan madrasah tidak cukup mempunyai kemampuan konseptual semata, namun perlu juga ditopang oleh technical skill (kemampuan teknik) dan human skill (kemampuan hubungan kemanusiaan). Yang kami maksud dengan kemampuan teknik adalah kemampuan

\footnotetext{
${ }^{29}$ Syaiful Bahri Djamarah, Guru dan Anak Didik dalam Interaksi Edukatif, (Jakarta: Rineka Cipta, 2000), h.37

${ }^{30}$ Dra. Mottiara, Guru, Wawancara, di MA Al-Falah Arungkeke Jeneponto.

${ }^{31}$ Sahertian, Konsep Dasar dan Teknik Supervisi Pendidikan: Dalam Rangka Pengembangan Sumber Daya Manusia, (Jakarta: Penerbit Rineka Cipta, 2000), h. 18.
} 
personal yang berhubungan erat dengan penggunaan alat-alat, prosedur, metode dan teknik dalam suatu aktivitas manajemen secara benar. Sedangkan, kemampuan hubungan kemanusiaan merupakan kemampuan untuk menciptakan dan membina hubungan baik, memahami dan mendorong orang lain sehingga mereka bekerja secara suka rela, tiada paksaan dan lebih produktif. ${ }^{32}$

Dari apa yang dikemukakan oleh salah satu unsur pimpinan madrasah tersebut diatas, maka secara umum bentuk keterampilan manajerial yang saat ini dibutuhkan oleh seluruh stakeholder yang ada MA Al-Falah Arungkeke Kabupaten Jeneponto meliputi kemampuan konseptual, kemampuan teknik, dan kemampuan hubungan kemanusiaan. Hal ini sejalan dengan pernyataan dan sekaligus harapan dari salah seorang guru, Wahidah, S.PdI, yang mengatakan bahwa sesungguhnya dampak besar dari kemampuan manajerial yang dimiliki oleh kepala madrasah dalam mengelola institusinya secara keseluruhan, akan turut menentukan kinerja kami (guru) di madrasah ini.

Olehnya itu, antara keterampilan manajerial dan kinerja pegawai khususnya kinerja guru terdapat korelasi yang positif dan kuat. Sebab, semakin tinggi tingkat kemampuan manajerial kepala madrasah, semakin tinggi pula tingkat kinerja para guru di lingkungan madrasah itu sendiri. Hal itu ditandai dari intensitas pembelajaran yang dilakukan oleh para guru semakin meningkat serta adanya keinginan yang kuat dari para guru untuk mengembangkan profesi dan kompetensinya masing-masing.

Menurut seorang guru MA Al-Falah Arungkeke Kabupaten Jeneponto bernama Aminah, S.PdI, yang mengemukakan bahwa "jika kita ingin menghasilkan mutu lulusan yang bagus dan mendapatkan situasi madrasah yang efektif dari segi sistem manajemen pengelolaannya, maka hal pertama yang harus jadi perhatian bagi semua komponen madrasah adalah bagaimana menafsirkan konsepsi dari pimpinan madrasah yang terjawantah kedalam bentuk kerja sesuai job-discriptionnya masing-masing. Di samping itu, pola kepemimpinan yang dihadirkan di lingkup madrasah ini harus bersifat aspiratif dan akomodatif. Aspiratif yang dimaksud adalah pimpinan madrasah seyogyanya mampu mengidentifikasi, cermat melihat dan peka mendengar keinginan bawahan atau seluruh stakeholder madrasah (bottomup) dalam kerangka semangat pengembangan madrasah. Sedangkan akomodatif adalah pimpinan madrasah tanggap terhadap keinginan arus bawah selama dalam orientasi tercapainya visi-misi dan tujuan madrasah (top-down)." 33

\footnotetext{
${ }^{32}$ Sumaryanto, S.PdI, Guru, Wawancara, di MA Al-Falah Arungkeke Jeneponto.

${ }^{33}$ Aminah, S.PdI, Guru, Wawancara, di MA Al-Falah Arungkeke Jeneponto.
} 
Menilik dengan cermat pernyataan guru tersebut di atas, maka figur kepala madrasah yang diinginkan oleh para guru dalam rangka pengembangan kinerjanya adalah tidak sekedar mempunyai keterampilan manajerial melainkan juga mempunyai kepemimpinan yang baik (aspiratif dan akomodatif). Sebagai gambaran dari hal tersebut, maka daapat dilihat dari tabel berikut;

\section{Tabel 5}

Pandangan Guru, dan Siswa terhadap Kemapuan Manajerial serta Kepemimpinan di MA Al-Falah Arungkeke Jeneponto

\begin{tabular}{|c|c|c|c|}
\hline No & Kategori Jawaban & Frekuensi (F) & Presentase $(\%)$ \\
\hline 1 & Sangat Baik & 8 & $5,9 \%$ \\
\hline 2 & Baik & 103 & $76,3 \%$ \\
\hline 3 & Tidak Baik & 18 & $13,3 \%$ \\
\hline 4 & Sama Sekali Tidak Tahu & 6 & $4,5 \%$ \\
\hline & Jumlah & 135 & 100 \\
\hline
\end{tabular}

Sumber Data: Hasil Olahan Angket No.5

Berdasarkan tabel di atas, menunjukkan kategori jawaban responden yang sangat variatif, yakni kategori jawaban sangat baik 8 responden atau 5,9\%, kategori jawaban baik 103 responden atau 76,3\%, kategori jawaban tidak baik 10 responden atau 13,3\%, dan kategori jawaban tidak tahu sama sekali sebanyak 6 responden atau 4,5\%.

Jika dicermati pilihan responden terhadap kategori jawaban di atas, maka secara umum masih di dominasi oleh kategori jawaban baik. Hal ini mengindikasikan bahwa dua variabel yang diteliti (kemampuan manajerial dan kepemimpinan) dalam lingkup MA AlFalah Arungkeke Kabupaten Jeneponto dianggap baik. Civitas madrasah seperti pegawai, guru dan siswa melihat bahwa pimpinan madrasah selama ini telah menunjukkan kemampuannya dengan senantiasa mendorong, membimbing, mengarahkan, menggerakkan mereka dalam rangka mencapai tujuan yang telah ditetapkan.

Fakta ini dikuatkan dengan pandangan beberapa pimpinan, guru, dan siswa sendiri, diantaranya ialah;

Menurut Dra. Rosminah, wakamad kurikulum, yang berpandangan bahwa "secara umum kemampuan manajerial dan kepemimpinan kepala madrasah kami menunjukkan performa yang baik khususnya dalam membuat rancang-bangun madrasah sebagai proyeksi masa mendatang. Cuma memang harus diakui bahwa masih terdapat beberapa kekurangan di 
beberapa hal, seperti kurangnya jaringan atau pihak-pihak lain yang terkait untuk bekerja atau berperan serta dalam proyek pengembangan pendidikan di madrasah ini. Olehnya itu, kedepan yang menjadi catatan penting adalah bagaimana pimpinan madrasah mampu kreatif dan lebih dinamis dalam merangkul serta menjalin kerjasama multipihak demi tercapainya output yang sesuai dengan visi MA Al-Falah Arungkeke Jeneponto, yakni terciptanya madrasah aliyah yang unggul berwawasan kebangsaan, berbudaya Islami dan berdedikasi tinggi." 34

Sedangkan menurut Burhan, siswa, mengemukakan bahwa "para pimpinan madrasah terlebih kepala madrasah ini telah memimpin dengan penuh keteladanan. Pimpinan madrasah secara umum juga mampu menampilkan sikap yang adil dalam setiap permasalahan siswa lainnya, baik yang berkaitan dengan akademik maupun ekstrakurikuler."35

Dari pernyataan faktual para guru dan siswa tersebut, maka penulis menarik kesimpulan bahwa dari keterampilan manajerial kepala Madrasah Aliyah Al-Falah Arungkeke Jeneponto yang bermuatan kemampuan konseptual, kemampuan teknik, dan kemampuan humanitas, maka berimplikasi positif kepada kinerja guru yang dibuktikan dengan efektifitas madrasah seperti pada bidang administrasi dan lainnya serta kepuasan siswa dalam pembelajaran.

\section{KESIMPULAN}

Berdasarkan analisis terhadap pembahasan dari penelitian ini, maka dapat ditarik kesimpulan bahwa:

1. Bentuk keterampilan manajerial kepala MA Al-Falah Arungkeke Jeneponto yang teraktualkan dalam kemampuan konseptual, kemampuan teknik, dan kemampuan hubungan dengan sesama manusia. Dengan kemampuan manajerial kepala madrasah yang memadai, maka dengan mudah memimpin dan menggerakkan semangat kerja dan performance para guru dan seluruh komponen madrasah secara lebih optimal serta menghasilkan pula manfaat bagi madrasah pada umumnya dan secara personalitas dari tiap komponen pada khususnya.

2. Dalam konteksnya dengan keterampilan manajerial, kepala MA Al-Falah Arungkeke Jeneponto mampu menyusun perencanaan madrasah untuk berbagai tingkatan perencanaan, mengembangkan organisasi madrasah sesuai dengan kebutuhan, memimpin madrasah dalam rangka pendayagunaan sumber daya madrasah secara optimal, memiliki

\footnotetext{
${ }^{34}$ Dra. Rosminah, Guru, Wawancara, di MA Al-Falah Arungkeke Jeneponto.

${ }^{35}$ Burhan, Siswa, Wawancara, di MA Al-Falah Arungkeke Jeneponto.
} 
strategi yang tepat untuk meningkatkan kinerja tenaga kependidikan di madrasahnya. Menciptakan iklim madrasah yang kondusif, memberikan nasehat kepada warga madrasah, memberikan dorongan kepada seluruh guru, serta melaksanakan model pembelajaran yang menarik.

Berdasarkan pengamatan atau hasil dari penelitian ini, maka implikasi kepemimpinan kepala madrasah jika ditinjau dari kompetensi manajerialnya ditandai dengan frekuensi yang tinggi. Artinya bahwa jawaban responden terhadap beberapa varian pertanyaan terkait dampak dari model dan gaya kepemimpinan kepala madrasah berada pada kisaran di atas rata-rata. Sedangkan rata-rata skor maksimal tersebut berada pada rentang nilai 70 $-85 \%$ maka pengkategorian nilai berada pada posisi "baik".

\section{DAFTAR RUJUKAN}

Dede Rosyada, Paradigma Pendidikan Demokratis: Sebuah Model Pelibatan Masyarakat dalam Penyelenggaraan Pendidikan, Jakarta: Penerbit Kencana, 2004.

Departemen Agama RI, Al-Quran \& Terjemahnya, Jakarta: CV. Alwah, 1995.

Dirjen Depag RI, Pedoman Manajemen Berbasis Madrasah, Dj.II; Dirjen Depag RI, 2003.

Depag RI, Landasan, Program dan Pengembangan Kurikulum Madrasah Tsanawiyah, Jakarta: Ditjen Bimbagais, 2002.

Departemen Agama RI, Al-Quran \& Terjemahnya, Semarang: PT. Karya Toha, 2002.

Departemen Agama RI, Al-Quran \& Terjemahnya, Jakarta: CV. Alwah, 1995.

Hasbullah, Dasar-Dasar Ilmu Pendidikan, Jakarta: Penerbit PT. RajaGrafindo Persada, 1999.

Ibrahim Bafadal, Peningkatan Profesionalisme Guru Sekolah Dasar, Bandung: Remaja Rosdakarya, 2000.

John M. Echols dan Hasan Shadily, Kamus Inggris-Indonesia: An English-Indonesian Dictionary, Jakarta: Penerbit PT. Gramedia, 1997.

Diknas RI, Kamus Besar Bahasa Indonesia (KBBI), kbpp-offline., 2012.

Kartini Kartono, Pemimpin dan Kepemimpinan, Cet.IV; Jakarta: Rajawali Press, 1993.

Lexy J. Moleong, Metodologi Penelitian Kualitatif, Bandung: Remaja Rosdakarya, 2000.

Malayu SP. Hasibuan, Manajemen: Dasar, Pengertian, dan Masalah, Jakarta: Penerbit Bumi Aksara, 2001. 
Mulyasa, Manajemen Berbasis Sekolah: Konsep, Strategi dan Implementasi, Bandung: PT. RajaGrafindo Persada, 2002.

Nana Sudjana dan Ibrahim, Penelitian dan Penilaian Pendidikan, Bandung: Sinar Baru, 1989.

Nanang Fatchurochman, Madrasah Sekolah Islam Terpadu, Plus dan Unggulan, Depok; Lentera Hati Pustaka, 2012.

Noeng Muhajir, Metodologi Penelitian Kualitatif, Yogyakarta: Rake Sarasin, 2000.

Nawawi, Kepemimpinan dalam Pendidikan, Surabaya: Usaha Nasional, 1994.

Ngalim Purwanto, Administrasi dan Supervisi Pendidikan, Bandung: Penerbit PT. Remaja Rosdakarya, 1998.

Nurcholis Madjid, Spiritualitas Kaum Muda, Sebuah Pembacaan Tematik, Cet.VII; Jakarta: Gramedia, 1995.

Nur Uhbiyati, Ilmu Pendidikan Islam (IPI), Jilid 1, Bandung: CV Pustaka Setia, 1998.

Sondang P Siagian, Fungsi-Fungsi Manajerial, Jakarta: Penerbit Bumi Aksara, 1992.

Sri Minarti, Manajemen Madrasah, Mengelola Lembaga Pendidikan secara Mandiri, Yogyakarta: Ar-Ruazz, 2011.

Sutopo, Administrasi, Manajemen dan Organisasi, Jakarta: Lembaga Administrasi Negara, 1999.

Syaiful Bahri Djamarah, Guru dan Anak Didik dalam Interaksi Edukatif, Jakarta: Rineka cipta, 2000.

Ulbert Silahahi, Studi tentang Ilmu Administrasi: Konsep, Teori, dan Dimensi, Bandung: Sinar Baru Algensindo, 2002. 